\title{
WORKPLACE HEALTH PROMOTION IN THE CONTEXT OF AGING WORKFORCE IN EUROPE
}

\author{
Stela L. Georgieva \\ Department of Public Health Sciences, Faculty of Public Health, Medical Uni- \\ versity-Pleven, Bulgaria.
}

\begin{abstract}
:
The global process of population aging and changes in labour force participation models increase the median age of the working population. The increasing number and proportion of employed at age 60 and more inevitably affect workplace health promotion and is a challenge to all employers, companies and countries. The purpose of this article is to analyze the attitude of the society in European countries to the problem of the aging workforce, the extent to which employers assess specific health needs of older workers, and their willingness to adapt working conditions to them. The analysis is based on data collected by the European Agency for safety and health at work (EU-OSHA) in the framework of the Pan-European survey on occupational safety and health, the International Monetary fund (IMF), Organisation for Economic Co-operation and Development (OECD), country profiles etc. The majority of employers consider that older workers are less productive, less adaptable to changes in the workplace, and therefore more at risk of stress. They confirm the necessity of programs and policies which make the working environment more friendly to old workers. At the same time, organizations which already implement such policies is low in most European countries. It varies from $1 \%$ to $24 \%$ in different countries. Although they are aware of the risks to which workers over the age of 60 are exposed, the development and implementation of health promotion programs in the workplace, addressing the specific needs of older workers, is not a widespread practice.
\end{abstract}

Keywords: aging labour force, Europe, workplace health promotion,

\section{INTRODUCTION:}

The global process of population aging and changes in labor force participation models (the labor force is people ages 16 and older who are either working or actively looking for work), increase the median age of working population [1, 2]. Demographic characteristics of human capital are changing (more intensive in developed countries) due to life expectancy increases, fertility restrictions, enhanced education and training needs, health care and public health innovations improving health, respectively mental and physical capacity to increasingly late ages $[3,4]$. Various reasons may be considered in relation to the aging workforce [5]:

- Financial: A lack of a proper pension plan and reforms of the systems of retirement in many countries left many people with debts or insufficient income from their pension [5].

- Demographic: Fertility rates in developed countries from the year 1965 until now is rapidly decreasing and stationed at low levels. New generations are fewer than the previous ones. Therefore, the demographic replacement rate is decreasing while the elderly dependency ratio and aging in- dex are increasing [6]. On the other hand, people get healthier, and the mortality rate is decreasing as a result of better nutrition, improving hygiene and health care. As a result, life expectancy and the period of productivity for both men and women generally increases, and they are asked to stay longer at work $[3,7,8]$.

- Social: Many people enjoy the social aspects of having a job, they like to feel productive, and they prefer to stay longer at work.

Improvement of health, living and working conditions and community development leads to an increasing number of people who are physically and cognitively capable of work at 60 years of age and more. More and more people are working into their later years. There is considerable evidence of scientific research and prognosis that the trend is expected to continue during the future decades, and the proportion of old workers will increase. Different interpretation of "old workers" are available in different documents $[9,10]$. In this article we consider as "old workers" working people over 60 years of age. For example, about 35\% of people aged 60 and more were working or actively looking for work in the USA in 2014. That number, known as a labor force participation rate, is expected to increase in 2024. In contrast, participation rates of most other age groups in the labor force aren't projected to change much in this period. According to the Organisation for Economic Co-operation and Development (OECD), European Commission and International Monetary Fund (IMF), the trend is similar in Europe (fig. 1). The process is particularly intense in countries such as Spain, Hungary, Italy, Greece [11] (tabl. 1)

Fig. 1. Europe: Share (\%) of working population by age groups in the years 2014 and 2035.

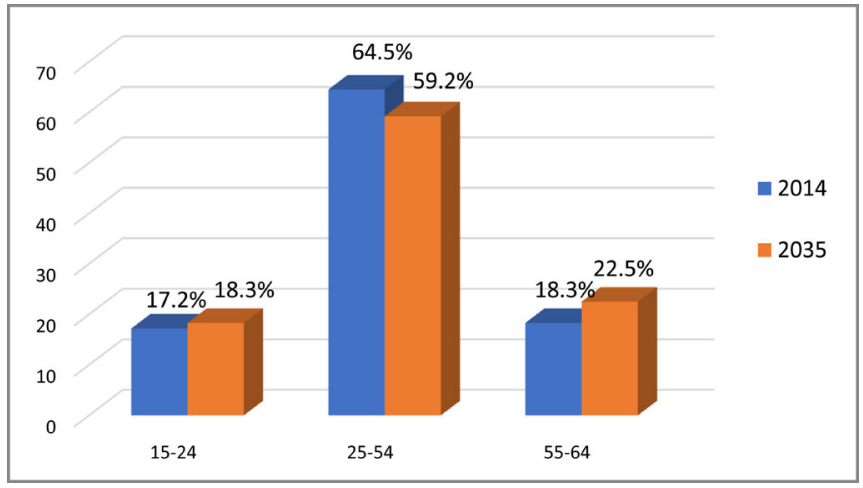

Sources: OECD; European Commission; and IMF staff calculations. 
Tabl. 1. Projected workforce aging in selected European countries (relative shares of workers aged 55-64 years to the labor force)

\begin{tabular}{|c|c|c|c|c|c|}
\hline Country & 2014 & 2020 & 2025 & 2030 & 2035 \\
\hline Austria & 11.3 & 15.6 & 16.9 & 16.3 & 15.5 \\
\hline Belgium & 12.9 & 16.6 & 16.4 & 15.9 & 15.7 \\
\hline Bulgaria & 18.3 & 21.3 & 22.8 & 24.2 & 25.4 \\
\hline Check Republic & 15.5 & 15.0 & 16.3 & 20.0 & 23.7 \\
\hline Denmark & 16.3 & 19.2 & 20.3 & 20.3 & 19.2 \\
\hline Estonia & 17.8 & 18.9 & 19.1 & 20.8 & 21.7 \\
\hline Finland & 18.2 & 18.9 & 18.3 & 16.7 & 16.8 \\
\hline France & 14.3 & 15.8 & 17.4 & 17.6 & 16.6 \\
\hline Germany & 18.2 & 22.0 & 23.7 & 21.7 & 20.1 \\
\hline Greece & 11.5 & 18.5 & 21.3 & 23.7 & 25.4 \\
\hline Hungary & 14.1 & 17.1 & 19.8 & 23.4 & 26.5 \\
\hline Ireland & 13.4 & 15.5 & 16.9 & 19.2 & 21.5 \\
\hline Italy & 14.8 & 19.9 & 23.6 & 25.8 & 25.8 \\
\hline Latvia & 16.8 & 18.1 & 18.5 & 19.3 & 19.0 \\
\hline Lithuania & 16.3 & 18.0 & 19.1 & 19.8 & 19.2 \\
\hline Luxemburg & 10.3 & 12.7 & 13.4 & 12.9 & 12.2 \\
\hline Netherlands & 16.2 & 18.5 & 20.2 & 19.6 & 17.8 \\
\hline Norway & 16.6 & 17.2 & 17.9 & 17.9 & 16.8 \\
\hline Poland & 14.5 & 14.2 & 14.4 & 16.7 & 20.4 \\
\hline Portugal & 14.9 & 18.4 & 20.4 & 22.5 & 24.1 \\
\hline Slovakia & 13.6 & 14.9 & 15.2 & 17.2 & 20.6 \\
\hline Slovenia & 11.4 & 17.2 & 18.9 & 19.3 & 20.4 \\
\hline Spain & 13.1 & 19.0 & 22.2 & 25.4 & 27.5 \\
\hline Sweden & 18.0 & 17,9 & 18,6 & 18.8 & 18.2 \\
\hline United Kingdom & 14.7 & 16.8 & 17.6 & 17.0 & 15.9 \\
\hline
\end{tabular}

Sources: OECD; European Commission; and IMF staff calculations.

The increasing number and proportion of older workers make the question of workability of this cohort. Workability is the balance between work and individual resources; when work and individual resources fit well together, workability is good. The core factors affecting this are health and functional capabilities, education and competence, values, attitudes and motivation etc. Because of some restrictions of the functional capacity associated with age, it requires increased attention to protect their health and workability and qualitatively new thinking at a company, national and E.U. level $[12,13]$. The impact of aging on productivity may differ across different occupations. Workers with jobs that require physical exertion, such as factory workers or workers in the construction sector, are likely to become less productive with age, while other professions are age neutral $[14,15]$. There are some professions in which productivity even increases with age (lawyers, managers, medical doctors), but as a whole, the health of the aging workforce is a challenge for all employers, companies and policymakers at the national and international level [12, 16, 17].
The purpose of this article is to analyze the attitude of the society in European countries to the problem of the aging workforce, the extent to which employers assess specific health needs of older workers, and their willingness to adapt working conditions to them.

\section{MATERIAL AND METHODS:}

National and international databases were used for the purpose of the study. The analysis is based on data collected by The European Agency for safety and health at work (EU-OSHA) in the framework of Pan-European survey on occupational safety and health, International Monetary fund (IMF), Organisation for Economic Co-operation and Development (OECD), comparative analysis of the country profiles etc. Data analysis includes 27 countries that currently form the European Union (EU27) and countries of the European Free Trade Association (EFTA), consisting of four European states: Iceland, Liechtenstein, Norway, and Switzerland. 


\section{RESULTS AND DISCUSSION:}

The prospect of the increasing number and share of workers over 60 years of age is not equally assessed in different European countries and groups of countries. It was assessed as probable and possible by $56 \%$ of the citizens of EU15 (the 15 countries that formed the European Union until 1st May 2004) countries, and only by 36\% in countries of Central and Eastern Europe, most of which joined to E.U. in the years 2004 and 2007 (MMS12) [18] (fig. 2).

Fig. 2. Proportion (\%) of European citizens who assess the probability for increasing number of workers over 60 as likely or unlikely for their countries

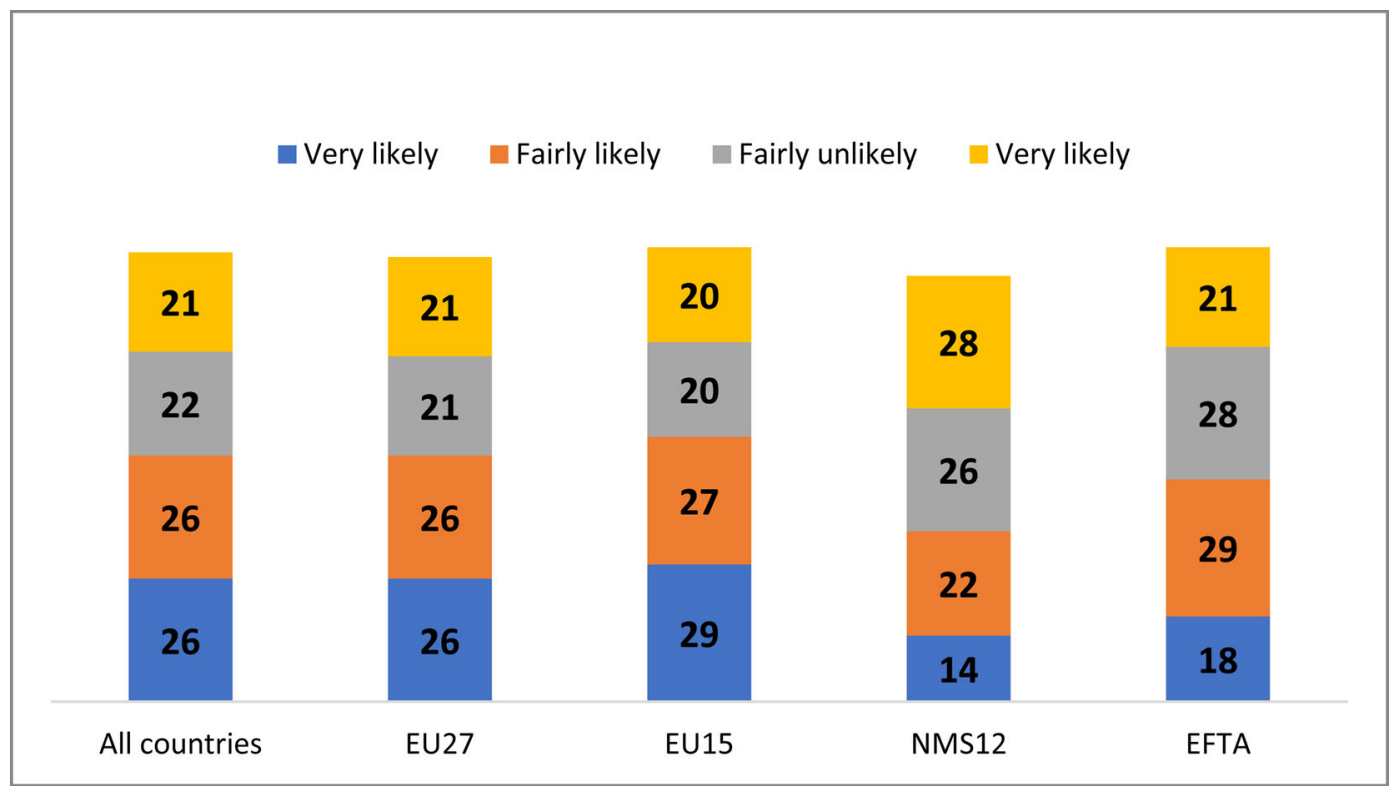

The proportion of citizens and employers who think that old workers take more time off work due to illness, have more accidents at work and be less productive at work is relatively low. At the same time, it is widely believed that older workers are generally less adaptable to changes and especially to innovations at the workplace, and therefore more at risk of stress. The proportion of people that think so varies from $43 \%$ to $83 \%$ in European countries (on average $60 \%$ for the Region and EU27) [18] (fig. 3)

Fig. 3. Proportion (\%) of European citizens who think older workers tend to be less adaptable to changes at work than other workers

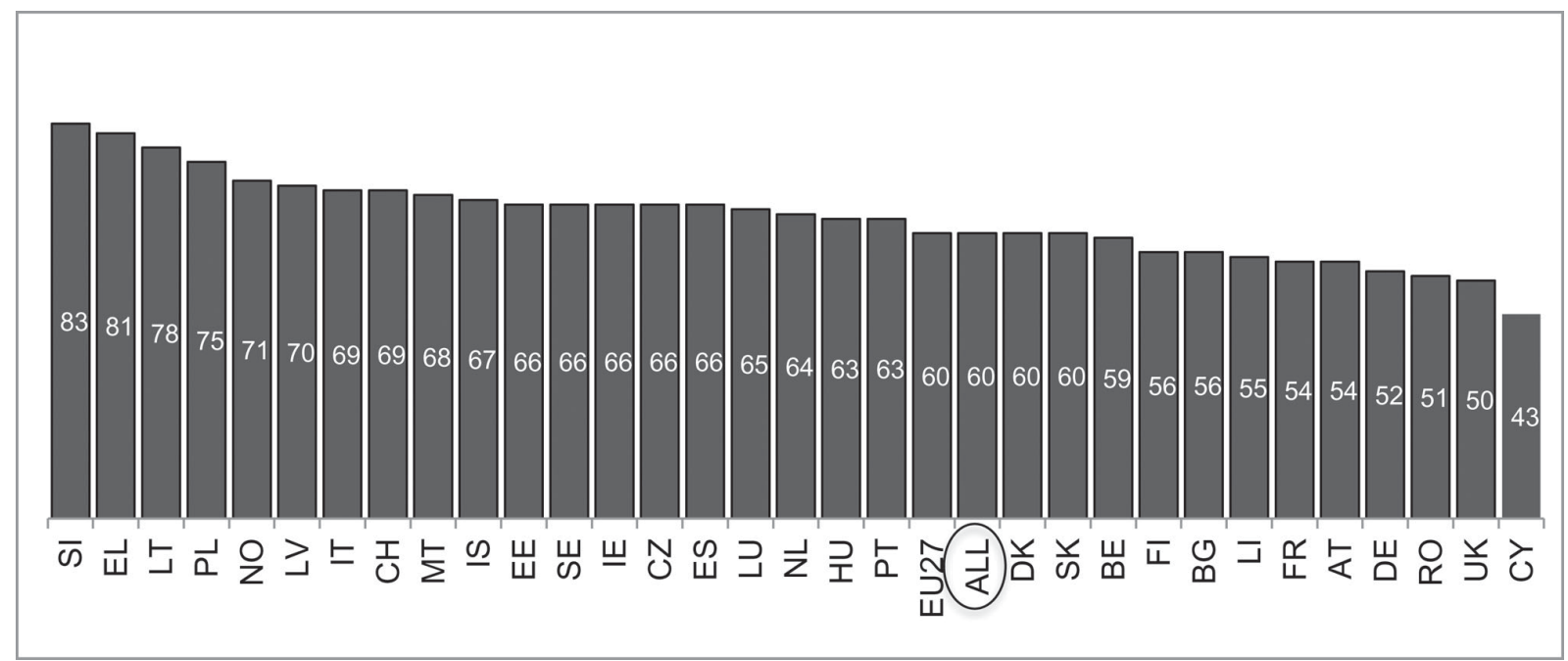

Less than half of European citizens (42\%) support the view that older workers are at greater risk of occupational diseases. The variation between the countries on this indicator is very pronounced - from 11 to $70 \%$ (fig. 4).
On the other hand, scientific studies provide considerable evidence about the association between occupational disease and longer exposure to the working environment [18]. 
Fig. 4. Proportion (\%) of European citizens who think older workers tend to suffer more from work-related stress than other workers

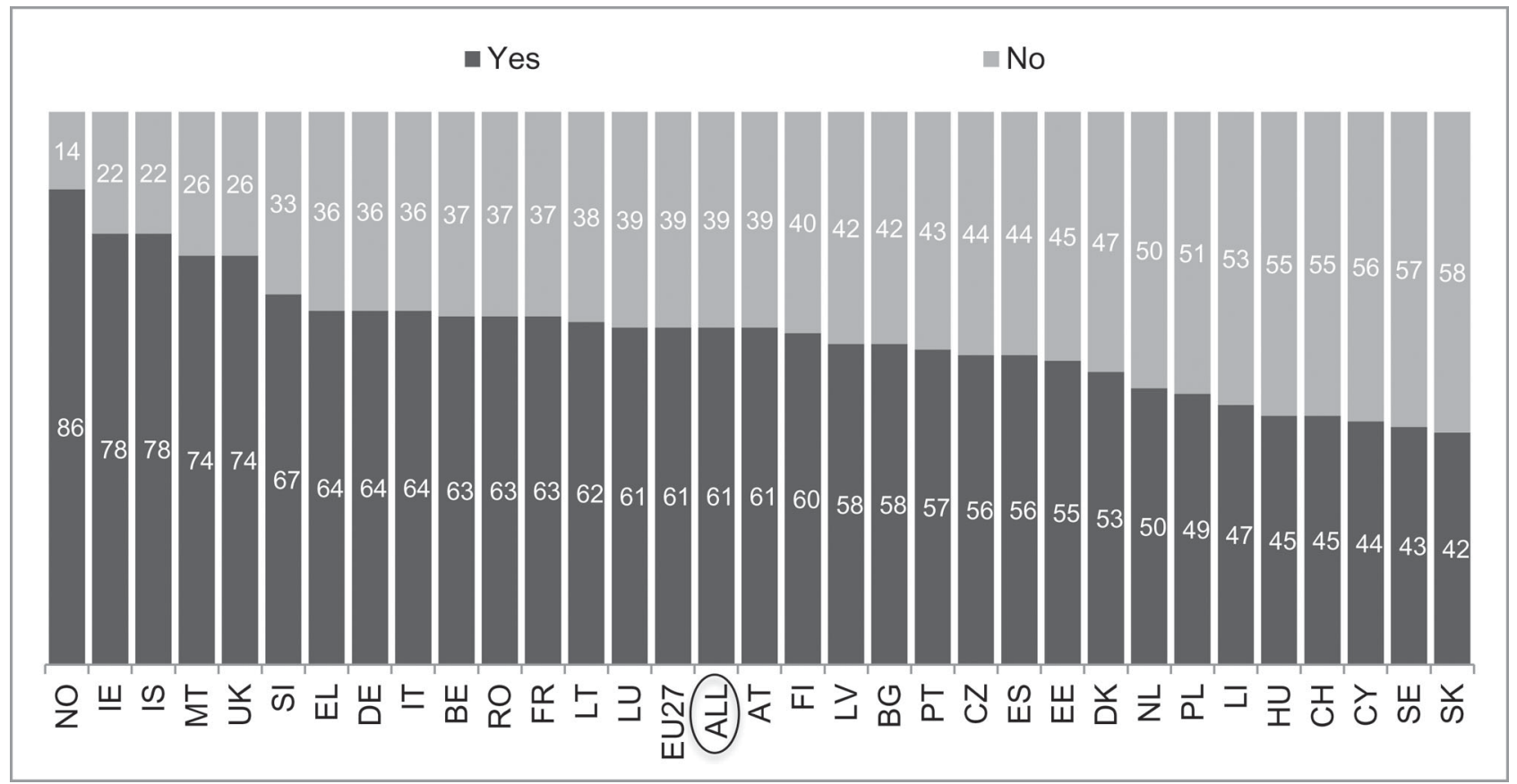

An opinion poll conducted by the European Agency for Safety and Health at Work shows that a large proportion of E.U. citizens and employers believe that good health and safety practices are important and help people work longer. A well-organized workplace is useful for all age groups, including older workers. Age-related reduction of the physical and sensory capacity of the body requires adaptation of the working environment and work regime, aimed at reducing the likelihood of errors and accidents. This adaptation includes reorganization or rotation of the workplace, more short breaks, better organization of shift work, for example, through accelerated shift rotation (2-3 days), adequate lighting and noise control, good ergonomic equipment design etc. [18, 19]. As it is visible in fig. 5 , the majority of them $(58 \%)$ respond positively to the question of the necessity of programs and policies which make the working environment more friendly to old workers. In contrast, organizations which already implement such policies is low in most European countries. It varies from $1 \%$ to $24 \%$ in different countries (fig. 6). Only $1 / 3$ of respondents accept the probability of an increasing number of people over the age of 60 in their organizations as a real problem [18].

Fig. 5. The opinion of European citizens about the necessity of health promotion programmes or policies at the workplace directed to older workers $(\%)$

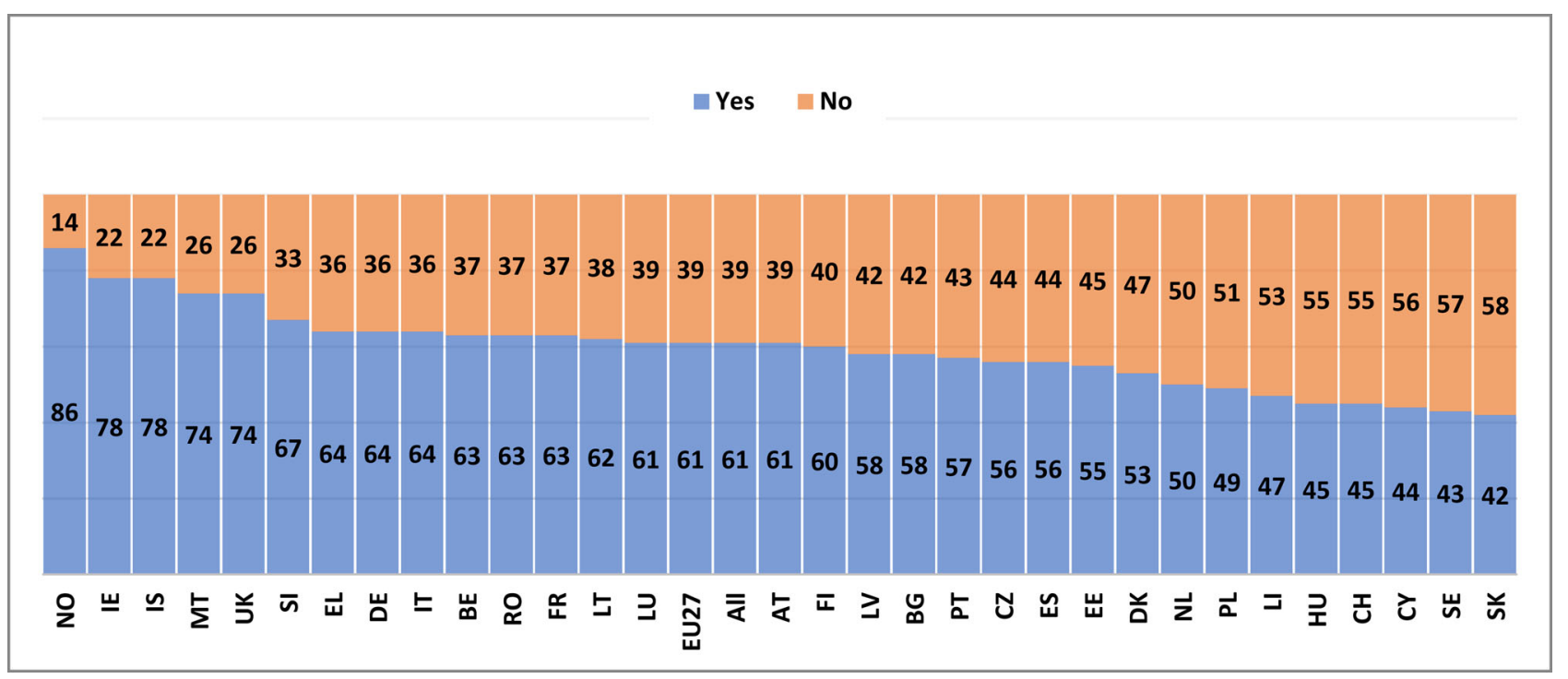


Fig. 6. The proportion of companies who already implement programmes or policies directed to needs opinion of older workers $(\%)$

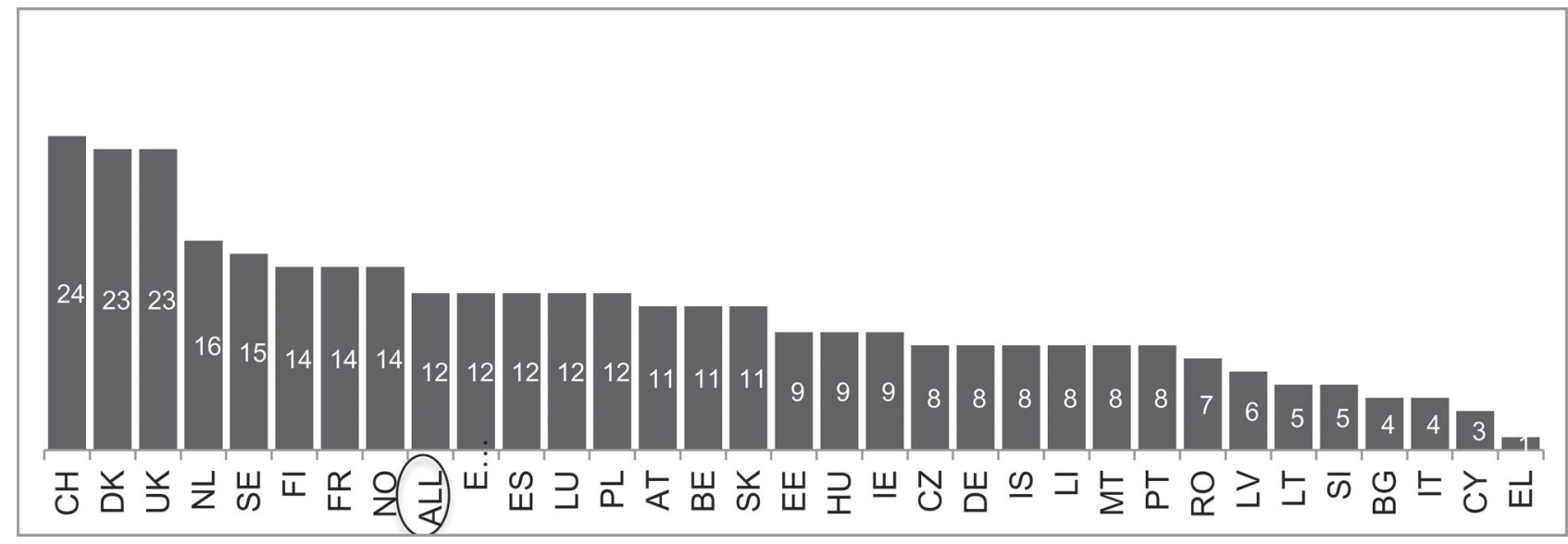

\section{CONCLUSIONS:}

- An in-depth analysis of a number of international institutions on the processes of population aging and the labour market predicts that the relative share of workers aged 60 and over in Europe will increase.

- The impact of aging on health and workability requires increasing attention on workplace health promotion.

- The probability of an aging workforce and the related effects are underestimated in a number of European countries.

- Although the idea of introducing health promotion programs and policies in the workplace aimed at older workers is welcomed by citizens, the number of organizations that already implement such a policy is very low.

\section{Abbreviations:}

OECD - Organisation for Economic Co-operation and Development

IMF - International Monetary Fund

EU-OSHA - European Agency for safety and health at work

EFTA - European Free Trade Association

CEE - Countries of Central and Eastern Europe

EU27 - The 27 countries that currently form the European Union

EU15 - The 15 countries that formed the European Union until 1st May 2004

NMS12 - New Member States (The 12 countries that joined the European Union in 2004 and 2007)
Two-letter country designations used in charts:

AT-Austria

BE-Belgium

BG-Bulgaria

$\mathrm{CH}-$ Switzerland

CY-Cyprus

CZ-Czech Rep.

DE-Germany

DK-Denmark

EE-Estonia

EL-Greece

ES-Spain

FI-Finland

FR-France

HU-Hungary

IE-Ireland

IS-Iceland

IT-Italy

LI-Liechtenstein

LT-Lithuania

LU-Luxemburg

LV-Latvia

MT-Malta

NL-Netherlands

NO-Norway

PL-Poland

PT-Portugal

RO-Romania

SE-Sweden

SL-Slovenia

SK-Slovakia

UK-United King

ALL-All countries

\section{REFERENCES:}

1. The 2018 Ageing Report Economic\&Budgetary Projections for the 28 EU Member States (20162070). Institutional paper 079. EC. May 2018. [Internet]

2. Carone G, Eckefeldt P, Giamboni
L, Laine V, Sumner SP. Pension reforms in the EU since the Early 2000's: Achievement and Challenges Ahead. Discussion paper 042. EC. December 2016. [Internet]

3. Glossary of Demographic Terms.
PRB. 2015. [Internet]

4. Manton KG, Lowrimore GR, Ullian AD, Gu XL, Tolley HD. Labor force participation and human capital increases in an aging population and implications for U.S. research invest- 
ment. PNAS. 2007 Jun 26;104(26): 10802-10807. [Crossref]

5. Tamburo JJ, Switzer E, Gower WS. Lessons from the Diversity Partners Project: Using knowledge translation to strengthen business engagement strategies and improve employment outcomes for job seekers with disabilities. J Vocat Rehabil. 2019; 50(3):291-299. [Crossref]

6. Society at a Glance. OECD Social Indicators. 2006 Edition. OECD. 2007. 117 p. [Crossref]

7. Georgieva SL, Kambourova MS. Population aging - a present day public health problem in Bulgaria. EIIC 2016: Proceedings in Electronic International Interdisciplinary Conference: the 5th Electronic International Interdisciplinary Conference, 8-12 August 2016.

8. Afework B, Campbell A, Hanania J, Stenhouse K, Donev J. Population replacement rate. Energy Education. July 21, 2018. [Internet]
9. Pensions at a Glance 2017: OECD and G20 Indicators. OECD Publishing, Paris. 2017. [Crossref]

10. Toossi M, Torpey E. Older workers: Labor force trends and career options. Career Outlook, U.S. Bureau of Labor Statistics, May 2017. [Internet]

11. Aiyar S, Ebeke C, Shao X. IMF Working paper. The Impact of Workforce Aging on European Productivity. IMF. December 2016. [Internet]

12. OSH management in the context of an ageing workforce. Promoting workability and workplace health promotion. European Agency of Health and Safety at work. [Internet]

13. Chatterji S, Byles J, Cutler D, Seeman T, Verdes E. Health, functioning, and disability in older adultspresent status and future implications. Lancet. 2015 Feb 7;385(9967):56375. [PubMed]

14. Stoilova I, Birdanova V, Dekov D. Technological process, working conditions and health injuries to work- ers in the production of eggs and poultry. Trakia Journal of Sciences. 2018; 16(Suppl. 1):126-129. [Crossref]

15. Stoilova IJ, Dekov DP, Birdanova VA. [Production factors and health impairments in forestry workers.] [in Bulgarian] Health policy and management. 2019; 19(2):206-10.

16. Smalligan J, Boyens C. Policies for an Aging Labor Force. Keeping Older Workers with Health Conditions Employed. Urban Institute. October 19, 2020. pp.4-7. [Internet]

17. Aging Workforce Challenges: Trends, Statistics and Impact. AIHR Academy. [Internet]

18. European opinion poll on occupational safety and health. EUOSHA. May 2013 [Internet]

19. Pescud M, Teal R, Shilton T, Slevin T, Ledger M, Waterworth P, et al. Employers' views on the promotion of workplace health and wellbeing: a qualitative study. BMC Public Health. 2015 Jul 11;15:642. [PubMed]

Please cite this article as: Georgieva SL. Workplace Health Promotion in the context of aging workforce in Europe. $J$ of IMAB. 2022 Jan-Mar;28(1):4217-4222. DOI: https://doi.org/10.5272/jimab.2022281.4217

Received: 05/11/2021; Published online: 01/02/2022

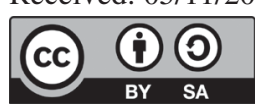

\author{
Address for correspondence: \\ Stela Georgieva \\ Department of Public Health Sciences, Faculty of Public Health, Medical Uni- \\ versity - Pleven \\ 1, St. Kliment Ohridski str., 5800, Pleven, Bulgaria \\ E-mail: georgieva_s1@yahoo.com
}

